AperTO - Archivio Istituzionale Open Access dell'Università di Torino

\title{
Challenging Prison Officers' Discretion: “Good Reasons” to Treat Courteously Mafiosi in Custody in Italy
}

\section{This is the author's manuscript}

Original Citation:

Availability:

This version is available http://hdl.handle.net/2318/1679610

since 2021-03-13T11:36:51Z

Published version:

DOI:10.1177/0891241617749012

Terms of use:

Open Access

Anyone can freely access the full text of works made available as "Open Access". Works made available under a Creative Commons license can be used according to the terms and conditions of said license. Use of all other works requires consent of the right holder (author or publisher) if not exempted from copyright protection by the applicable law. 


\title{
Challenging prison officers' discretion: "Good reasons" to
}

\section{treat courteously mafiosi ${ }^{1}$ in custody in Italy}

\author{
Luigi Gariglio ${ }^{2}$
}

\begin{abstract}
Prison ethnography has long touched on the central role of prison officers' discretion. Nowadays, a large number of sociologists and criminologists share the assumption that prison officers have de facto to resort to discretional decisions continuously to be able to translate the law into practice as they go about their job. This paper addresses the topic of prison officers' discretion differently by adopting Analytic Autoethnography and Emotional Recall. It outlines four officers' "good reasons" for cooperating with mafiosi in custody-treating them with good manner-rather than showing neutrality as they would do with "ordinary" prisoners. The main "good reasons" that ground mafiosi-officers relationships are: 1) reciprocal institutional recognition that Italian criminal justice and high-ranking mafia prisoners recognize one another; 2) mafioso capacity to help officers to "govern" fellow prisoners in practice; 3) the social embeddedness of the mafia both inside and outside prison and, lastly, 4) prison officers' fear of retaliation.
\end{abstract}

\section{Keywords}

Discretion, Mafia, Organized crime, Prison officer, Analytic Autoethnography, Emotional Recall

\section{Introduction}

\footnotetext{
${ }^{1}$ I prefer to use the words mafioso, mafiosi without capital letters rather than mafia rather than Mafioso, Mafiosi and Mafia. I really do not agree to use a capital letter. I use mafioso for both male and female components of the mafia, mafiosi for the plural, and mafia to refer to any organised crime group.

${ }^{2}$ University of Turin, Italy.
} 


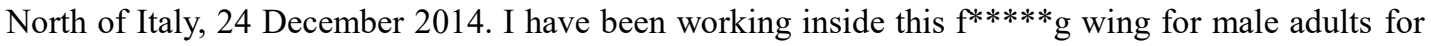
some months, mainly working side-by-side with officers in just one wing for many hours a day. I have been following their interventions after so-called critical ${ }^{3}$ events time and again. I'm starting to feel that it's too much. Situations start to become disgusting or boring; occasionally annoying; many routines and interactions, even serious or violent ones, start to appear like déjà $v u$; sometimes even officers' and prisoners' small talk becomes disturbing. I simply need a break, I'm starting to feel almost anesthetized, as well as, concurrently, vulnerable, traumatized, and unsure. Can I bear all this? Everything happening in front of me seems kind of the same, and I cannot distinguish what's right or wrong any more; I need to quit the field for some time. Sometimes I cannot refrain from crying and that's not normal for me at all. I do not feel crying to be appropriate in here. I am afraid of my tears, they are unacceptable to me; I am not used to crying; I am proud to be considered (and to consider myself) to be kind of cynical most of the time. However, slowly, slowly, I feel I am changing; now I'm starting to feel differently and I don't like it. (Vignette 1. Ex post reconstruction of my thoughts and emotions after an interview with a prison social worker)

The narrative above (Vignette 1) is only one possible reconstruction of what I now remember and feel about what I felt when I broke down in tears in front of Gino ${ }^{4}$. It is a partial outcome of only a short cross-section of emotions of the "forgotten" video clip I shall introduce shortly below.

\section{Some memories of my research experience on prison officers" "use of force" have}

been continued to trouble me even now. By the end of the field experience I simply felt

that I needed to continue interrogating myself via my memory and my research material

to tackle those memories thoroughly.

I 've just had a nervous crisis [2 seconds pause]. I felt hysterical. I suddenly felt very bad and got worried about myself. Now I'm leaving the prison and going downtown. It's two o'clock. I must stop interviewing ...eh...be-because ...Andrea [a prisoner] died this morning, and I just experienced a prison officer's assault. I can't stand it all. It is overwhelming. The social worker just told me not to come back any time soon, at least for a few weeks.

(Verbatim transcript of the video clip; my translation).

Above you can read the verbatim transcript of the video clip I referred to in Vignette

1. In that video clip I had recorded myself talking in front of a mirror in a prison toilet.

\footnotetext{
${ }^{3}$ Critical event are "constructed" as such by officers: Examples od critical events include: an inmate refusing to respond to a lawful order; a prisoner refusing to entering the cell quickly after exercise; a prisoner-prisoner fight; a prisoner destroying his cell; or a prisoner assaulting an officer.

${ }^{4}$ All the names in this paper are pseudonyms.
} 
That toilet was located next to Gino's office. He was a social worker whom I was interviewing before I broke down in tears and rushed from his office into that toilet to hide. I recorded that video clip immediately after the emotional crisis I experienced, which persuaded me to stop interviewing Gino. I now have the feeling that I can remember clearly what occurred back then; I can also remember that I recorded that video in order to fix my thoughts with the intention of transcribing them afterwards. I used the camera to "scribble" my thoughts because I was feeling unable to use my pen and paper notebook due to my emotional state and my shaking hands. I stopped interviewing and then I quickly left Gino's office to enter the bathroom next door. After a short time, I regained control of my emotions and started recording a few words. That clip is dated 24 December 2014, at 11:34. The length of the clip is only 26 seconds, during which I talk to myself in Italian in front of the mirror.

That short video clip remained hidden in my ethnography archive, among a lot of other visual material, for more than two years. Afterwards, I realised that not only is it the only video clip produced as a substitute for a written note on paper, but also that I never returned to that clip during the analysis; it seems that I had removed it from my memory. Unexpectedly I "discovered" that short and apparently insignificant video clip when looking at the available empirical material for the nth time. Now I know that that video clip elicited my emotion, which in turn triggered my need to reflect more and, eventually, to write this paper. Reviewing the research material all over again with a new cognitive and emotional attitude, I was able to tackle my disturbing memories and, at the 
same time, produce new reflections. By watching that short video footage, I experienced for the first time what Ellis (1999) calls a "process of emotional recall".

\section{Ellis's Emotional Recall}

I appreciate Ellis's attention to the complex, ambivalent and even contradictory nature of emotions (Ellis 1991), and her lesson on "emotional recall" (Ellis 1999) as a heuristic tool in constructing an autoethnographic (or highly reflexive ethnographic) account. However, what actually compelled me to adopt her approach was my personal and unpredictable experience related above. Ellis describes Emotional Recall by writing:

I use a process of emotional recall in which I imagine being back in the scene emotionally and physically. If you can revisit the scene emotionally, then you remember other details. The advantage of writing close to the time of the event is that it doesn't take much effort to access lived emotions - they're often there whether you want them to be or not. The disadvantage is that being so involved in the scene emotionally means that it's difficult to get outside it to [analyse] from a cultural perspective. Yet, both of these processes, moving in and moving out, are necessary to produce an effective autoethnography. $(1999,675)$.

In an effort to address some disturbing memories and personal emotions that were not in focus in the ethnography (Gariglio 2017), I decided to "return" to the scene vicariously by reconsidering all those materials all over again. ${ }^{5} \mathrm{By}$ re-reading what I had written while watching again the images and the videos I had produced during fieldwork, and by re-observing and listening to the original video-recording focussing on this new disturbing memory of mine, I was able to experience differently what I had already experienced during fieldwork. ${ }^{6}$ My process of Emotional Recall was facilitated by the large quantity of recorded visual material and video interviews that almost literally dragged me back into the ethnographic field as a means of eliciting and stimulating many

\footnotetext{
${ }^{5}$ These practices were first introduced by Cicourel et al. (1974). Thanks to the anonymous reviewer.

${ }^{6}$ Some of the new autoethnographic findings were introduced at the last minute in my forthcoming publication (Gariglio 2017).
} 
memories, emotions and thoughts. Images worked even better than written accounts (Gariglio 2016a). I would wish others to be open to emotional Emotional Recall; it could help them to challenge, or just make more complex and multifaceted, their previous understanding and/or description of the field (Wakeman 2014). However, I would also advise researchers to be cautious. I testify that Emotional Recall on sensitive issues can be daunting and draining for the researcher, and might initiate new stress and strong emotions. Old trauma or unbearable experiences might re-emerge in different and unpredictable forms. Nevertheless, I agree with Bosworth's comment that 'anxiety is part of process.' We just need to bear it in one way or another.

\section{My experience of Emotional Recall}

Strangely enough, despite forgetting for quite some time that critical interview with the social worker that ended in tears, I have continued to remember the short violent critical episodes that preceded that interview (Vignette1), which probably influenced what occurred. As far as I can recall, I was following one officer taking a group of prisoners to exercise in the yard, which by then was for me just an everyday routine. Returning to the wing from the yard about an hour and a half later with the same officer and group of inmates, I was involved in a so-called "critical event" in which a prisoner assaulted the officer who was leading us. A prisoner, suddenly and for no apparent reason, hit the officer hard in the face. It all occurred just a few steps from me. The incident took place on the stairs when the officer, the prisoner and I were about to enter the wing. A prisoner also pushed me to the ground unintentionally. I fell onto the floor without any physical consequences, although I did feel strong emotions, pain and fear. 
That embodied and emotional experience of the assault, and my physical participation in it, enhanced my participation in the field. It was a turning point both for me and for the officers who soon learned what had happened. On that occasion I learnt a valuable lesson on the toughness and unpredictability of officers' work. I had also learnt a lot about my vulnerability and myself. That same morning, a few hours before the assault, I had been puzzled by the news of the death of a prisoner in custody in "my" wing, someone whom I had both photographed and interviewed. Furthermore, strangely enough, a mafioso had behaved unreasonably and (verbally) abusively, and even threatened to start throwing some food out of his cell; as far as I know officers turned a blind eye and did not threaten force. Despite the assault I experienced, and with the prisoner's death clearly fixed in my memory, no trace of that "failed interview" or of that mafioso's behaviour was incorporated into any text of mine.

Some of the questions I ask myself about what occurred and why I did not pay much attention at the time, are:

Why were some episodes (temporarily) deleted from my active memory? Why, at the time, did I consider them marginal within the ethnography rather than crucial? Can it tell us anything about my relationships in the field and about my research agenda? What about my research practice? Can it help to disclose any hidden, unconscious, political dimensions in my practice? What would have happened if I had a more feminine attitude or if I had been in a gender-mixed context or in a female prison? Do I still incorporate and reproduce masculine codes to such an extent as not to be able to accept the display of any weakness of mine under any circumstance? Was I simply worried about losing my research access by showing my emotional side to the officers, thereby undermining my reputation of toughness, which allowed me to participate in emergency interventions? How can I try to describe the complexity of these emotions? To what extent does what I am feeling now relate to what I felt back then?

I do not have clear answers yet. But, following a reviewer's suggestion, masculinity should be more explored. I think it might deserve a paper to itself; masculinity, however, is only a part of the picture, and it will not be dwelt upon here. For now, I am simply able 
to disclose my interrogatives publicly, and try to focus on the four prison officers' "good reasons" instead. It is not much, yet it feels like a first step in the right direction.

By becoming more and more aware of those discretional and legal prison officers' attitudes (and practices) toward mafiosi via Analytic Autoethnography (Anderson 2006), my indignation urged me to try to comprehend better sociologically the possible motives for such practices. Despite my indignation and moral judgement on those practices, which initially I would see only in terms of unfairness or injustice, I then decided to work more analytically on my recalls and the available research data. In other words, I tried to move beyond indignation and moral judgment (which persisted anyway), trying by so doing to seek sociological empirical comprehension of plausible prison officers' "good reasons" to exercise discretion in a particular way with particular prisoners. What emerged clearly is that the two main prisoners groups are: mafiosi and non-mafiosi (or “ordinary prisoners"). ${ }^{7}$ In this paper I focus on mafiosi in custody. I have no intention to justify such officers' attitudes and practices; rather I intend to tackle such practices empirically from a sociological perspective.

\section{The experience of officers' discretionary attitudes toward organized crime}

\section{prisoners}

I now introduce an example of a memory of mine regarding officers' discretionary attitudes toward organized crime prisoners:

Umberto is one prisoner kept in the wing. He is alone in his cell and is looking aloof as he usually does. He is often quite rude with other prisoners, yet he seems to be respected by most of them.

\footnotetext{
${ }^{7}$ Each of these macro groups can then be further divided. Although culturally the boundaries between the first and the second groups are fuzzy, criminal justice treats them differently, as will become clear.
} 
Compared with his fellow prisoners, he shows a different type self-confidence by staring at others directly in their eyes. Yet he is treated with an extraordinary level of respect by his peers most of the time. Prison officers too often show respect to him too; rarely do they challenge his ideas or conduct in public (at least, I have never witnessed it). However, despite reciprocating respect, he shows no particular gratitude for their "good manners". Umberto is even allowed by officers to be verbally semi-abusive towards other prisoners, and more rarely towards low-ranking staff and rookies. Prison officers come and ask him what he needs each and every time he requests it, as officers do with any mafiosi on the wing. If Umberto were another prisoner, just another — "ordinary" — prisoner acting like this, he would be treated very differently. Inexplicably, he is always treated well, independently of his behaviour; a justification is always available to mitigate the possible consequences of Umberto's wrongdoing. He is not just any prisoner; he is a mafioso. As such, he apparently deserves special treatment (Vignette 2).

Vignette 2 is one ex-post narrative reconstruction of a kind of plausible situation that I now think I experienced on few occasions-each time the situation occurring in a different way. What is constructed and described in that narrative did not attract my attention until the final phase of the ethnography. If it had attracted me before, I would possibly have collected more data on the topic. However, my topic was demanding enough attention, focussing on lawful prison officers' intervention and use of force during so-called "critical event" (Gariglio 2016b).

What I recall now is that anybody convicted for organized crime would be, more likely than not, received respectful treatment on the wing rather than neutrality. Officersmafiosi relationships would be characterized by cooperation and recognition, rather than coldness or distance, which would be more often the case with the "ordinary prisoners". Mafiosi were consistently treated respectfully both by other convicts and by the officers. None of the mafiosi critical behaviours or acts of resistance, such as refusing to enter the cell after yard exercise, which were rare but still did occur, was ever labelled, either formally or informally, as a "critical event" in my presence. None, therefore, ever triggered the threat of the use of force (as far as I know). All sorts of prisoners except mafiosi were frequently threatened with force in front of me. A higher degree of 
tolerance, negotiation and inducement (Kauffman 1988; Crewe 2009) was more often displayed towards mafiosi, the staff dealing with their requests and complaints consistently and efficiently. Likewise, mafiosi's comments about staff, when talking to me, as well as behaviour towards them were usually more formal and respectful than those of other prisoners. There were exceptions, though, as Vignette 2 shows.

The discretional (morally unfair) officers' way of treating mafiosi was not clearly visible during the fieldwork, or at least it did not attract my attention; it only emerged clearly as a possible research topic afterwards. It appeared suddenly and clearly in my recall that prison officers would cooperate with mafiosi most of the time. I then started to reason about the possibility of looking for prison officers' "good reasons" for doing so, beyond other possible explanations such as officer prejudice, corruption or other forms of favouritism (see below).

Mafiosi were treated courteously, yet their prison regime was harsh. In fact, they were locked in their cells most of the time and did not have any right of access to the communal yards; they would be sent to special concrete yards with nothing in them except a few fellow prisoners. Rather than focussing on the extreme cases in which officers consistently favoured mafiosi by turning a blind eye to a particular mafioso's critical event (Vignette 2) or favouring them in one or another illegal way, I will focus here on the ways in which officers used discretion to treat mafiosi day-in-day-out, adopting their available area of lawful discretion (see the section below entitled "Beyond discretion: favouritism"). 


\section{Ideas on discretion, negative discrimination and favouritism}

Prison ethnography has long touched on the central role of prison officers' discretion (Sykes 1958). Nowadays, most prison sociologists share the assumption that prison officers de facto have to resort to discretional decisions continuously, as they go about their job, to be able to translate the law into practice (Liebling 2000). Some researchers also agree that discretion is not applied randomly: on the contrary, the race, ethnicity, and gender of both prisoners and officers have an impact on officers' discretion as to how they implement one particular rule on one particular occasion in one particular way with a particular human being.

\section{On Discretion}

"Prison Officers, Policing and the Use of Discretion" (Liebling 2000) is a key contribution to address head-on the issue of discretion in contemporary prison studies. It is worth noting that "[ $\mathrm{t}]$ he concept of discretion is at home in only one sort of context; when someone is in general charged with making decisions subject to standards set by a particular authority" (Dworkin 1977, 31), which is precisely the type of context this paper is about: routine mafiosi-officer interactions. This paper will not address empirically extreme cases of (unlawful) favouritism.

In sociology, the topic of discretion was first raised as a fundamental feature of social interactions by ethnomethodology (Garfinkel 1967; Cicourel 1968). 
Lipsky $(1969,2010)$ is another liminal sociologist working on the topic who focussed his attention on street-level bureaucrats, including prison officers; he offers a well-known interpretation of discretion, which argues that in street-level bureaucracies, particularly with "non-voluntary clients" (Lipsky 2010, 54-56) held in coercive public agencies such as prisons or police departments, 'workers interact and have wide discretion over the dispensation of benefits or the allocation of public sanction' (1980, xi). Lipsky's theorization fits well with the interpretation of prison officers' working practices and discretion (see Bennett, Crewe, and Wahidin 2008; Crawley 2013).

Dworkin's perspective is grounded on the Philosophy of Law. His work can help to address discretion from a different perspective. In his book Taking Rights Seriously (1977, vii), Dworkin analyses the concept of discretion more thoroughly within his liberal theory of law. Dworkin shows the boundaries of the concept by specifying that "[t]he concept of discretion is at home in only one sort of context; when someone is in general charged with making decisions subject to standards set by a particular authority [...] It makes sense to speak of the discretion of a sergeant who is subject to order of superiors" $(1977,31)$. In order to illustrate his own interpretation of discretion, he adopts a very clear metaphor: "[d]iscretion, like the hole in the doughnut, does not exist except as an area left open by a surrounding belt of restriction" $(1977,31)$. That metaphor expresses the way in which discretion depends on the context in which it takes place and on the legal framework constraining it. In the fieldwork where the study was conducted, the normative "surrounding belt of restriction" of wing officers' discretion was the Italian Constitution, Prison Law and the so-called (local) Prison Orders that are lawful 
procedures and rules that specify what officers can and cannot do in practice when dealing with prisoners, as well as some limited forms of internal and external accountability. Those laws, rules and regulations ought to restrict the officers' discretionality in their day-to-day interactions with prisoners; however, such belts of restriction are not always respected and might allow the emergence of forms of favouritism with high-ranking prisoners.

\section{Beyond discretion: a few ideas on arbitrariness and favouritism}

It is worthy remembering that the space of discretion is bordered by laws, rules, and regulations. Following the critical scholar David Scott (2008), prison officers can exercise discretion in three ways: (i) formal discretion consists of clearly-defined options explicitly written in laws and regulations; (ii) provisional discretion implies less-clearlydefined options that are nonetheless subject to-at least internal-accountability procedures or external review; lastly, (iii) ultimate discretion "which arise[s] when the decision-making process is not subject to internal monitoring or has only restricted external review" (Scott 2008, 69). I would rather call ultimate discretion simply arbitrariness. Arbitrariness could lead to either negative discrimination (Castel 2007) against low-ranking prisoners, or favouritism towards high-ranking groups of prisoners; in Italian prisons, mafiosi are the highest-ranking group.

I do not deny that I witnessed officers' favouritism toward mafiosi inside; I have, and Vignette 2 shows it. ${ }^{8}$ Here, I interpret favouritism as a form of arbitrary discrimination that privileges a powerful group for one reason or another. A review of

\footnotetext{
${ }^{8}$ Writing about the UK context, Scott (2008) writes that prison staff normally uses both formal discretion and provisional discretion. However, due to the scarce enforcement of penal accountability, he suggests, ultimate discretion could also enter the picture.
} 
definitions of favouritism is not possible here. Three classes of favouritism are usually described in the literature: (i) nepotism, (ii) cronyism, and (iii) corruption. I will not consider nepotism or cronyism because they are not pertinent to the topic of this paper. It is noteworthy, however, that in the literature of organized crime officers' corruption, it is considered as a relevant form of interaction between law enforcing agents and organised crime. I do not dismiss it; I simply have no heuristic grounds for such an interpretation because I have not witnessed, or heard about, any case of corruption occurring in the last ten years or so. Von Lampe (2016), on the contrary, suggests that organized crime might influence prison officers' behaviour by offering bribes. "The typical scenario is that criminal[s] pay [...] prison guards, in exchange for favourable treatment" (267).

Without dismissing von Lampe's suggestion, which resonates very well with popular culture, and the mythologies of both mafia and prison, I turn now to the substantive part of the paper in which I tackle officers' "good reasons" for using discretion with mafiosi as they usually do in the realm of discretionary day-to-day officer-prisoner interaction. In the next section, I will focus on day-to-day relationships imbued in discretion that structures prison life inside the custodial complex as I experienced it. By doing so I "stand on the shoulders" (sensu Merton) of about sixty years of sociological and criminological research focussed on discretion. However, I will do it slightly differently; rather than describing or criticizing the "fuzzy boundaries of discretion" theoretically from a moral prospective, I will target some particular officers' "good reasons" for discretionally treating mafiosi politely in their daily interactions that emerged from my experience in the field. I will do this by trying to separate my 
emotional and civic anger and indignation, which will show anyway, from the empirical study of officers-mafiosi relationships.

\section{Officers, mafiosi and good manners: unpacking officers' "good reasons"}

In this section I focus on officers' rationale for interacting discretionally with mafiosi trying to collaborate rather than be neutral and detached with them, as they normally do with the ordinary prisoners. Notwithstanding the large international literatures on both mafia (and organised crime) and prison, to the best of my knowledge this is the first empirical paper in the EU context-grounded on participant observation and interactions with both mafiosi in custody and their keepers-dealing with this topic. During the ethnography more than a dozen mafiosi lived for at least a few weeks on the wing. Some prison scholars have already alluded to organized crime (Crewe 2009). Others have noticed officers' "good manners"-or at least cooperative attitudes-towards other kinds of powerful prisoners: Jacobs (1974) e.g. studied prison gangs. It is almost commonsensical that "[officers] are under strong pressure to compromise with their captives" (Sykes 1958: 58), and that in order to do so, officers often use discretion. Following Liebling, Price and Shefer (2011), in prison there would be "a continual tension between the intrinsic caste-like gap between staff and prisoners, on the one hand, and the bridging of that gap that is necessary if the task of 'getting through the prison day' is to be accomplished smoothly" (2011: 134).

The point that is relevant here, however, is that such 'pressure for compromise' or the 'necessity to bridge that caste-like gap' showed a structured patterned outcome in the 
field that could be observed by the researcher; Moreover, ideas of compromise and discretion were often present, either explicitly or not, when officer were chatting to one another or with me about their work.

\section{“Mafiosi are gentlemen": officers describing mafiosi in custody ${ }^{9}$}

Mafiosi were often described by prison officers as "good prisoners", unlike "all the others" and this is nothing new for prison staff working on the wing in Italy. It was a common refrain that 'I boss sanno farsi la galera' (Bosses know how to behave properly when 'doing time'); in other words, according to officers, mafiosi have the competence, material and symbolic resources to adapt to prison better than others. Mafiosi, or more in general powerful prisoners, as hinted above, enjoyed more respect and recognition both in Italy and in the UK. As Crewe $(2009,264)$ suggests, "Powerful prisoners rarely caused problems....Staff normally commented that they were normally 'chatty and friendly to staff, and very polite' (senior officers)". The relationships between officers and powerful prisoners were usually characterized by a presentation of the self in which, on both sides, facework displayed the maintenance of civility, deference, formal respect and interactive accommodation (Goffman 1958). As Carlo, a front-line prison officer, put it:

[Mafioso] They are gentlemen; they respect me as a worker and never disturb me without a good reason [as other prisoners often do]. Therefore, I respect them and treat them accordingly. Usually, I try to respond each and every time they call me. They always say "please" and "thank you". (Field note: verbatim)

Re-reading that field note I recall Carlo telling me that as if it were a fact, or a shared interpretation of mafiosi inside. During fieldwork I slowly got used to such a shared assumption. Carlo's narrative implied a quasi-formal respect, if not a kind of

\footnotetext{
${ }^{9}$ This point is crucial and it is also clearly emerging in an on-going PhD study conducted in Italy by Martina Panzarasa at the University of Milan (tutor: Mario Cardano) that will possibly be entitled Mafia Organized Crime and

Prison: Mafia Women's Prison Experience and Practices in a High Security Section.
} 
admiration, for those powerful people who had been so brave and smart as to enjoy life thoroughly and to earn honour and respect from the people outside where they had carried out their criminal activity. I remember I did not feel those comments as being very problematic at that time; nor did I pay any attention when I heard them, simply considering them as Italian prison officers' common sense.

In the following sections, I shall introduce the four "good reasons", describing them in turn. The first "good reason" focuses on the (i) reciprocal institutional recognition between officers and mafiosi, which I will argue is at least in part the outcome of the special institutional arrangements that criminal justice enforces when they deal with mafiosi. The second "good reason"-which is in part linked to the previous one-is grounded on my direct observation on the wing; it refers to the (ii) mafiosi capacity to help officers de facto (but not de jure) to "govern" the ordinary prisoners; mafiosi, I will argue, do so by exerting some authority on their fellow prisoners, thereby helping custodians to do their job. The third "good reason" refers to (iii) the social embeddedness of the mafia. ${ }^{10}$ The last "good reason" points out (iv) prison officers' fear of retaliation, which is mainly relevant to rookie officers.

\section{The first "good reason": mafiosi-prison officers' reciprocal institutional recognition}

In an effort to develop my autoethnography more analytically, I tried to distance myself from my moral and ethical indignation in order to comprehend better, rather than judge, what was at stake in the mafiosi-officers interactions: what "good reasons" could help to explain it.

\footnotetext{
${ }^{10}$ I owe this title to Von Lampe (2016); his Chapter 9 is in fact entitled "the social embeddedness of organized crime"
} 
The existing cultural scholarship on the mafia (Santoro 2015; von Lampe 2016), adopting a quasi-non-evaluative approach (von Lampe 2016) — constructing the mafia as a political organization fighting for power, influence and recognition within a territory in which it operates-guided my understanding of one interesting aspect of what occurred behind bars in those officers-mafiosi interactions. By re-thinking "criminals" called mafiosi sociologically as agents of local organizations apt to compete in governing a particular territory with a certain degree of consensus (Santoro 2015; von Lampe 2016) — non only obtained by violence-I started to grasp a crucial aspect that imbued officers-mafiosi relationships; however, my personal repulsion against the mafia and mafiosi remained. The mafia can be considered as a particular social organization characterized by a particular set of rules, symbols, ideology and practice (Von Lampe 2016; Santoro 2015). However, the prestige of mafiosi in custody cannot only be comprehended by referring to the power and reputation that such mafiosi in custody imported from their territory (or mandamento), following the importation model described below (see the section below entitled 'The social embeddedness of the mafia').

The mafia, and this is the crucial point of the first "good reason", is institutionalised by a set of institutional practices enforced by criminal justice, which specifically addresses mafiosi in particular ways, as a high-ranking prison officers explained to me. Mafiosi are treated differently by the criminal justice system, thereby recognising and reinforcing the mafia's status both in the prison and outside. In Italy, there are entire prisons, or particular prison wings in which powerful "bosses" are kept in 
custody under a special prison regime (called 41 bis) because of their dangerousness and rank in the organized crime; moreover, only a special unit of prison officers (Gruppo operativo mobile, $\mathrm{GOM}^{11}$ )—a group with a very high reputation among colleagues, as explained by an ex-GOM officer who returned to work as a "normal" prison officer-is allowed to work with mafiosi in those facilities; GOM officers deal exclusively with mafiosi, often safeguarding their own anonymity by wearing a balaclava. There are also special groups of magistrates and prosecutors and police forces, dealing exclusively with the mafia. All these institutional arrangements and practices not only "construct" mafiosi as powerful citizens and prisoners, but they institutionalise them (and "construct them socially") as a different and coherent powerful group of persons and prisoners, recognized as such institutionally with the mafiosi label. Such institutional recognition is clearly visible in the main distinction both officers and prisoners make regarding prisoners: on the one hand there are mafiosi-ranking from top-ranking so-called "41 bis" to the lower-level mafiosi: A.S. ${ }^{12}$ - on the other, all other prisoners ${ }^{13}$. One mafioso, Mimmo, at a beginning of a video-recorded interview started his conversation with me as follow:

"I was a 41 bis [only high-ranking mafia bosses are classified as such] for many years; now they have declassified me and I am only an AS (high security). Everybody knows it and they all respect me because of my past. I also respect all the workers here. Their job is not is not an easy one. Some prisoners do not know how to behave." (Summary of an ethnographic interview).

It was the first time Mimmo spoke to me in that way. He was proud; I was puzzled and angry because of his self-esteem and arrogance. As I understood it, he immediately told me about his previous regime of detention (41 bis) because it would

\footnotetext{
${ }^{11}$ The existence of this specialized group of the prison officers was discovered during the research; a prison officers who served as GOM officers gave me some clue about it. Surprisingly, even the only scholar I know who is starting to work on mafiosi and prison by interviews was completely unaware of the existence of the GOM.

${ }^{12}$ High security mafiosi are classified as AS1, AS2 or AS3 (High security 1, or 2 or 3).

${ }^{13}$ Prisoners who are not mafiosi are called ordinary prisoners (comuni); ordinary prisoners can also be divided in different groups with higher or lower position and reputation inside.
} 
somehow certify his rank in the mafia, and more in general, his social position. By putting such emphasis on the incipit of our dialogue, Mimmo clearly indicated to me his mafia belonging, at the same time differentiating himself not only from other ordinary prisoners, but also from other mafiosi who did not have his pedigree but were classified "Alta Sicurezza (High security)". Nevertheless, when I interviewed Mimmo, he had already been declassified from 41 bis to A.S. It was emotionally very tough for me to interact with him: I found his blatantly displayed his sense of superiority almost unbearable, quite horrible. Although I still believe that the mafia is among the worst epidemic problems in my country, I learned to respect him as a human being.

We have seen that in Italy there are both mafiosi and other prisoners. The highranking mafiosi could be seen from the tidiness of their cells, the care they took of for their image, and for the quality of their food, which they shared with others. It was also easy to recognize a high-ranking mafioso from his interaction with lower-ranking prisoners, including other mafiosi. On some occasions, a mafioso would speak on behalf of a group of prisoners in dealing with officers. For example, when a mafioso decided to return to his cell from the yard in advance, urging other prisoners to follow him. The officers would ask each individual prisoner if he agreed to "lose" half an hour of exercise. They would usually all nod in return — very rarely would someone challenge the boss by disagreeing.

Front-line prison officers speaking spontaneously about a new mafioso arrival on the wing would show deference to him like a worker to a self-made man. Officers (if 
asked about it, which I did not do then, only afterwards), would probably challenge and criticize mafiosi deeds but at the same time appreciate their power and onore (honour), perhaps partly because of the "social embeddedness of the mafia" (see below).

Stories are often told by the media about a just-captured mafia boss congratulating police officers' and acknowledging their investigative capacity and professionalism. They hardly ever resist arrest, but behave in a most docile manner.

Such story may reflect non only the boss's recognition of the state, but also his awareness of the overwhelming resources dedicated to his arrest. Officers always greatly outnumber mafiosi, making resistance futile. Once in prison, they recognise prison law and their rights. They recognize that officers behave professionally with them, and publicly recognise officers' role as their keepers. one possible explanation for mafiosi respect towards officers and their authority is that this respect is reciprocal.

On the other hand, prison officers respect mafiosi not only because they were very powerful persons who made their careers often starting from nothing (Von Lampe 2016; Hess 1999)—and that power was institutionalised by the criminal justice as illustrated above. Officers respected mafiosi also because they "deserved it", for their "merits"; they would usually be "doing time" decorously and they would also cooperate —in "governing" (and controlling) the other prisoners and solving disputes.

\section{The second "good reason": "merit"}

Officers-mafiosi reciprocal respect and recognition was also reinforced by officers' day-to-day experiences on the wing and their discretional power. There were 
practical "good reasons" for treating mafiosi as they do: if memory serves, most of the time mafiosi adopted "correct" behaviour, showing respect and loyalty towards officers. This is less likely with ordinary prisoners. Officers' legal area of discretion allowed them to have an informal "enhanced" relationship with prisoners who deserved it.

Prison officers could even allow or forbid any prisoner to work or not because they had discretionary power to decide by deciding whether to 'issue a ticket' or to turn a blind eye in any particular circumstance. This is morally problematic; yet, discretion was visible in the everyday routine in every prison I have visited in The Netherlands, Poland, the UK, Finland and Portugal (Gariglio 2007). It is noteworthy, though, that those officers would take into account seriously any mafioso's request, and would deal effectively and promptly with each of those requests or would apologise to a mafioso if he were not able to comply. Officers would do so more consistently with mafiosi than with the others. In other words, mafiosi deserved their respect, and discretion gave officer a tool to implement it.

Another mafiosi merit was their capacity to informally govern their fellow prisoners on the wing and to solve disputes without bothering officers all the time, thereby avoiding critical event. They had a significant stake in "governing" lowerranking prisoners informally inside. Lower-ranking fellow-prisoners would grant respect to mafiosi as they do outside the walls. Mafiosi would exercise great influence over fellow prisoners due not only to explicit threats of violence but also to their reputation and some form of cultural hegemony, which is, I would say, at stake inside the 
prison, in a similar fashion as that described by von Lampe (2016; see next section) referring to the mafia's territories outside (Hess 1999; von Lampe 2016). By gaining cooperation from mafiosi, officers also gain the cooperation of the other prisoners on the wing, and by doing so, 'getting through the prison day' as reasonably and smoothly as possible; mafiosi would be informally allowed, even required, to take care of lowranking troublesome or "whiny" prisoners, as well as problematic newcomers and to solve disputes without making them official. This would only rarely require any degree of violence, which would not be executed directly by the high-ranking mafiosi.

Mafiosi and guards would often grant reciprocal recognition to each others' leaderships and cooperate, rather than be indifferent to one another, in order to 'have as few problems as possible on the wing'. The few occasions I recall on which a mafioso behaved badly, the officer turned a blind eye, rather than threaten coercion, at least in front of me. I recall one officer telling me in one of those situations "He [the mafioso] is not feeling well. He is a good prisoner, isn't he?"-I would frame that episode as favouritism, rather than discretion.

Inside maximum-security prisons for top-ranking mafia boss (41 bis), according to an ex-41bis mafioso prisoner responding to a question of mine, the relationship between mafioso and prisoner is very different; it is less cooperative-if cooperative at all-due to the homogeneity of the population (there are only mafiosi) and the very fact that such a prison regime is intended to urge mafiosi to "collaborate with criminal justice" to "eradicate" mafia-organized groups, or at least to limit their organized 
criminal capacity. According to an ex-GOM prison officer who had worked in different 41 bis regime wings, officers are often transferred from one prison to another to avoid familiarity with prisoners; prison officers and mafiosi would only grant formal respect or indifference to one another.

\section{The third "good reason": the social embeddedness of the mafia}

Three points are particularly interesting for our purposes here: (i) the recognition of the necessity to distinguish, also in terms of vocabulary, between what I called arbitrariness and discretion; "Discretion is not the unconstrained freedom to choose as advocates claim" (Scott 2008, 69); ultimate discretion, therefore, should be distinguished analytically from discretion and called arbitrariness; (ii) discretion is a shared social accomplishment "leading to patterned and predictable outcomes" (Scott 2008, 69); such social accomplishment occurs (partly) for practical purposes in a context imbued in power struggles; (iii) eventually, the outcome of the exercise of discretion is naturalised and 'taken for granted' by many, and possibly resisted somehow by minorities.

In an effort to comprehend some aspects of officers' exercise of discretion, either formal or provisional, I look at the patterned and practicable outcome that leads to officers' adoption of good manners with mafiosi. These good manners that I recalled and the few that I recorded, I argue, could be interpreted partly in the light of the social embeddedness of the mafia, both inside and outside the prison.

I will sketchily justify this interpretation by referring to the Irwin-Cressey Importation Model (1964), which states that inmates culture is imported into the prison from the outside, rather than being only the outcome of the socialisation to the particular 
(shifting and fuzzy) prison culture, values and norms characterizing every prison. Jacobs (1974) shows that social and cultural factors as well as prisoners' reputation in the outside world are directly reproduced inside. He claims, "in Illinois prisons the inmate organization is better understood as an extension of an identical organization imported from the streets of Chicago" (Jacobs 1974, 397). I must admit I have no data supporting the existence in prison of an "identical organization" imported from the territory; yet, according to my recalls, my family origin, and the relevant literature on the mafia's cultural traits, codes and behavioural style, I can recognise that inside prisons powerful mafiosi are often granted at least a ritualistic if not formal respect.

My experience is slightly different from Jacobs'. As far as I recall and I comprehended it, powerful mafiosi were hardly able, if at all, to import their mafia organizational model into the facility; yet, mafiosi honour (onore) and prestige, built on the social position, social loyalties, social ties, and social recognition in the outside world, was definitely imported into that facility, and ipso facto displayed by mafiosi, and recognized by almost all prisoners as well as by the majority of the frontline prison officers; officers knew that high-ranking mafiosi were different; officers were socialised to interpret mafiosi in that way (see above).

\section{The fourth "good reason": prison officers' fear for retaliation}

Prison officers-or the majority thereof-recognized, cooperated with, and respected mafiosi, for a plurality of plausible "good reasons"; those reasons can help to comprehend why officers use discretion with mafiosi as they do. Officers, however, 
might have yet another plausible "good reason" for doing so: the fear of retaliation. I would suggest neither to overestimate nor to deny it. Officers might fear mafiosi for cultural reasons. Fear in general, not only specifically fear of mafiosi, was a common trait disclosed by many officers in one on one ethnographic interviews and chats that I conducted during prolonged participant observation (Gariglio 2017). Rookie officers could fear mafiosi simply due to the dangerousness that is culturally associated with mafia in general in popular culture, such as TV series, films and novels as well as the myth of mafia power (Sciarrone 2009); this cultural fear was not very frequent as far as I recall, though. Mafia myths of (and actual) violent conduct, as well as the deeds of particularly violent serial-killers, circulated among young officers working on the wing also in the form of curiosity or "noir-stories" and were occasionally narrated to me, e.g. on the occasion of the arrival of a new mafioso.

Prison officers might not only fear mafiosi for cultural reasons and for the "reciprocal influence of myth and reality" (Hess 2011, 10), though; they might also have enough information and professional knowledge to know the "[m]afia ability to punish" (Smith and Varese 2001, 349) and the "[m]afia ability to kill" everywhere on the territory. "Every [m]afioso knows perfectly well, when all is said and done, where his power comes from. People are scared of being physically hurt, and, in addition, no one wants to risk being killed (Arlacchi 1992, quoted in Smith and Varese 2001, 352). One prison chaplain was killed in unexplained circumstances a few years before this study, a prison chaplain told me in a video-recorded interview. He did not seem so surprised about what had occurred back then; he also clearly considered death as a possible risk of 
his work. That interview was a very challenging one and provoked very intense Emotional Recall when I listened to it and watched it again to amend this article for resubmission. Prison is a place of violence, harm, and fear (as well as boredom); it is not an easy landscape to negotiate.

This is not to say that every mafioso has such power or that he is really interested in using it against a prison officers who behave unkindly; that seems very unlikely to occur. However, what is true is that mafiosi often perform 'credible commitments' (Campana and Varese 2013), by which they threaten violence if things do not go as they desire in the territory where they "govern". It is not unreasonable to think that it could also occur inside in particular circumstances. This rationale guiding officers' attitude and benevolent practice towards mafiosi might be even plausible in the Italian context at large considering the large proportion of prison officers who come from area of the country with a "high mafia infiltration". Those officers know all too well the way in which mafiosi are able to punish either the victim or his or her family. Mafiosi and lowranking prison officers coming from the same cultural milieu might either only share to a certain extent the "mafia culture" (Santoro 2007; see also Varese 2017), or might even be linked by social network ties directly or indirectly connecting criminal and public officials (von Lamp 2016). All these factors suggest considering fear of direct retaliation as a plausible "good reason", if not the most relevant one. Before concluding I now move to the methodology section in which I deal with Analytic Autoethnography (Anderson 2006). 


\section{The method(s) of autoethnography}

More than ten years ago Anderson stated, "Autoethnography has recently become a popular form of qualitative research" $(2006,373)$. Yet that's not true everywhere; in Italy, as well as elsewhere, autoethnography is still unaccepted and operates only at the "frontiers" of social science. It remains still true, certainly in Italy, that there is often some suspicion among sociologists in terms of how autoethnography might weaken "the case for sociology as science" (Ellis 1991, 27).

Autoethnography is certainly not a one-size-fits-all approach; neither is ethnography, though. Critics share common views against autoethnography focussing on, among other points, (i) solipcism and narcissism: also "intellectual masturbation" (Gobo 2008: 63), (ii) the absence of results and theorization, and (iii) the problem of being immune to peers' citicisms (Ploder and Stadlbauer 2016). Such criticisms are, if at all, more plausible with regard to evocative autoethnographies rather than Analytic Autoethnography, as it will be clear shortly. Anderson (2006) suggests a distinction or rather a continuum, between two opposite types of autoethnography. On the one hand there is Analytic Autoethnography, on the other, evocative autoethnography. According to Anderson (2006), "The five key features of analytic autoethnography [are] (1) complete member researcher (CMR) status, (2) analytic reflexivity, (3) narrative visibility of the researcher's self, (4) dialogue with informants beyond the self, and (5) commitment to theoretical analysis". All in all, Analytic Autoethnography seems to be more attuned to traditional ethnographic practices characterized by a strong emphasis on reflexivity (Anderson 2006; Atkinson 2006); that's possibly the reason why it attracts my interest, being an ethnographer adopting a stance informed by critical realism. Analytic 
Autoethnography tends to focus not only, and not mainly, on the researcher's self, but also on crucial social problems, and their comprehension.

On the other side of the continuum Anderson situates evocative autoethnographies, which are characterized by a postmodern approach more focused on text formats and language (Reed-Danahay 1997). Usually evocative autoethnographies are intended to be confessional, emotive, and detailed. Sometimes they appear to be less focussed on the ethnographic context. So far, in prison sociology and criminology, some researchers appreciate and use the method of evocative autoethnography; Jewkes (2011), for one, published a stimulating article on autoethnography in prison research in which she focussed on the role of the ethnographer's emotions and research experience which, according to her, is too often neglected in mainstream publications.

I decided to adopt the Analytic Autoethnography approach, and I did it as a neophyte, as consistently as I could: I did not have what Anderson (2006) calls complete member researcher status. Yet, my experience of the officers' assault, and of being pushed to the floor on that occasion as well as the psychological consequences that affected me afterwards - which often affect prison officers too- and the relationship that I still have with some officers, make my research status as close as possible to CMR. All that I have learned and the ways in which I have changed suggest that that my approach could fit quite comfortably if not completely" in the analytic autoetnography perspective. I am a sociologist doing interactionist ethnographic research. I agree with Atkinson when he states that autoethnography "is by no means incompatible with the 
long-standing analytic goals of interactionist (and other) ethnographic research" (2006, 400). Doing Analytic Autoethnography helped me to construct a more complex and reflexive picture of the ethnographic context under discussion, to emphasize my subjectivity in the writing, and more importantly, to grasp new substantial understanding of a sensitive topic. Ellis's Emotional Recall allowed me to feel comfortable using my memory in addition to recorded data, to use memory as a heuristic tool for my autoethnographic research and to allow the research process to inspire and change me.

\section{A Few Personal Reflections}

This paper addressed the prison officers' discretion focussing on prison officersmafiosi relationships in ordinary custodial institutions in Italy, by taking into account the normal ways in which officers and ordinary prisoners relate. By doing so, this paper unpacks some prison officers' "good reasons" for using discretion to treat mafiosi in custody with good manners, in an effort to gain cooperation, and to reduce conflict among prisoners on the wing, and thereby to be able to govern better the prison population as a whole.

This research does not deny other forms of possible explication of the phenomenon being studied, such as those usually included in the rubric of favouritism, and in particular, prison officers' corruption. However, it proposes four plausible officers' "good reasons" grounded on my first-hand experience, memories and Emotional Recall that might contribute to the comprehension of the phenomenon, independently of the presence or absence of officers' corruption. 
The first "good reason" focussed on the (i) reciprocal institutional recognition between officers and mafiosi that I argued was, at least in part, the outcome of the special institutional arrangements that criminal justice enforces when dealing with mafiosi, and does not enforce with the others. The second "good reason"-which is in part linked to the previous one- focussed on the (ii) mafiosi capacity to help officers in practice to "govern" the other prisoners on the wing; mafiosi, I argued, do so by exerting some authority over their fellow prisoners, helping custodians to do their job. The third "good reason" that emerged was (iii) the social embeddedness of mafia ${ }^{14}$ and, lastly, (iv) prison officers'fear of retaliation.

Those "good reasons" are not mutually exclusive and do not offer complete comprehension of the phenomenon: they are grounded on my research data and on my recall; they offer some "partial truth" (sensu Clifford) that might help to shed some light on an overlooked yet empirically and analytically relevant phenomenon. A large collective empirical effort is needed to start to tackle this and similar topics thoroughly by participant observation.

After being at first highly sceptical about it, I am now convinced of the worth of the heuristic value of Analytic Autoethnography as a research method. The research output clearly shows once again the value of this perspective. If we want social sciences to deal with their subjects as "flesh and blood" individuals, we must, as researchers, be touched by the research process and be open to public self-reflection and scrutiny. This goal can be reached by a plurality of perspective. However, we have to remember that, as

\footnotetext{
${ }^{14}$ I owe this title to von Lampe (2016); his Chapter 9 is in fact entitled "the social embeddedness of crime" (218-237).
} 
social scientists, our main goal is to tackle the world out there, trying to make sense of it, rather than simply indulge in endless self-reflection.

\section{Acknowledgements}

I would like to thank Mario Cardano and the anonymous reviewers for their invaluable feedback. I would also like to thank Martina Panzarasa, Alen Norris, and Doug Porpora for their suggestions on various stages of the manuscript.

\section{Declaration of Conflicting Interests}

The author declared no potential conflicts of interest with respect to the research, authorship, and/or publication of this article.

\section{Funding}

The author received no financial support for the research, authorship, and/or publi- cation of this article.

\section{Works Cited}

Anderson, Leon. "Analytic Autoethnography." Journal of Contemporary Ethnography 35, no. 4 (2006): 373-95.

Atkinson, Paul. "Rescuing Autoethnography." Journal of Contemporary Ethnography 35, no. 4 (2006): 400-404.

Bennett, Jamie, Ben Crewe, and Azrini Wahidin, eds. Understanding Prison Staff. London: Routledge. 2008. 
Campana Paolo and Federico Varese. "Cooperation in criminal organizations: Kinship and violence as credible commitments." Rationality and Society 25 (2013): 263289.

Castel, Robert. La Discrimination negative. Citoyens ou indigènes?. Paris: Édition du Seuil, 2007.

Cicourel, Aaron V. The Social Organization of Juvenile Justice. New York: John Wiley, 1968.

Cicourel Aron V. et. Al. (1974). Language Use and School Performance. New York: Academic Press, 1974.

Crawley, Elaine M. Doing Prison Work: The Public and Private Lives of Prison Officers. London: Routledge, 2013.

Crewe, Ben. The Prisoner Society. Oxford: Oxford University Press, 2009.

Dworkin, Ronald. Taking Rights Seriously. Cambridge (MA): Harvard University Press, 1977.

Ellis, Carolyn. "Sociological introspection and emotional experience." Symbolic Interaction 14 (1991): 23-50. 
Ellis, Carolyn. "Heartful Autoethnography.” Qualitative Health Research 9 (1999): 66983.

Fassin, Didier. Prison Worlds: An Ethnography of the Carceral Condition, Cambridge: Polity Press, 2017.

Garfinkel, H. Studies in Ethnomethodology. Englewood Cliffs, NJ: Prentice-Hall, 1967.

Gariglio, Luigi. Portraits in Prisons. Roma: Contrasto Books, 2007.

Gariglio, Luigi 'Photo-elicitation in prison ethnography: breaking the ice in the field and unpacking prison officers' use of force'. Crime, Media, Culture. 12, no. 3 (2016a): 367-79.

Gariglio, Luigi. "Threats of force by prison officers in a male custodial institution: An ethnographic account.” Etnografia e Ricerca Qualitativa. 2 (2016b): 286305.

Gariglio, Luigi. 'Doing Coercion'. An Ethnography of Italian male prison officers using force. London: Routledge, 2017.

Gobo, Giampietro. Doing Ethnography. London: Sage, 2008.

Goffman, Erving. "The Nature of Deference and Demeanor." American Anthropologist 58 (1958): 473-502. 
Hess, Henner. Mafia \& Mafiosi: Origin, Power and Myth. New York: NYU Press, 1999 [1970].

Hess, Henner. "Approaching and Explaining the Mafia Phenomenon: Attempts of a Sociologist”. Sociologica 2 (2011): 1-21.

Jacobs, James B. "Street Gangs behind Bars". Social Problems 21, no. 3 (1974): 395409.

Jewkes, Yvonne. “Autoethnography and Emotion as Intellectual Resources: Doing Prison Research Differently." Qualitative Inquiry 18, no. 1 (2011): 63-75.

Kauffman, Kelsey. Prison Officers and their World. London: Harvard University Press, 1988.

Liebling, Alison. "Prison Officers, Policing and the Use of Discretion." Theoretical Criminology 4, no. 3 (2000): 333-57.

Liebling, Alison, David Price, and Guy Shefer. The Prison Officer. Second edition. Abingdon: Willan Publishing, 2011.

Lipsky, Michael. Toward a Theory of Street-level Bureaucracy. University of Wisconsin: Institute for Research on Poverty, 1969. 
Lipsky, Michael. Street-level Bureaucracy: Dilemmas of the Individual in Public Services. 30th anniversary expanded edition. New York: The Russell Sage Foundation, 2010.

Ploder, Andrea, and Johanna Stadlbauer. "Strong Reflexivity and its Critics: Responses to Autoethnography in the German-speaking Cultural and Social Sciences." Qualitative Inquiry 22, no. 9 (2016): 753-65.

Reed-Danahay, Deborah. Auto/Ethnography: Rewriting the Self and the Social. Oxford: Berg, 1997.

Santoro Marco, ed. Riconoscere le mafie. Cosa sono, come funzionano, come si muovono. Bologna: Il Mulino, 2015.

Sciarrone, Rocco Mafie Vecchie Mafie Nuove (New edition) Rome: Donzelli Editore, 2009.

Scott, David. "Discretion". In Dictionary of Prisons and Punishment, edited by Yvonne Jewkes, and Jamie Bennett, 69-70 Collompton: Willan Publishing, 2008.

Smith Alastair and Federico Varese. "Payment, protection and punishment: The role of information and reputation in the Mafia." Rationality and Society 13, no.3 (2001): 349-393.

Sykes, Gresham M. The Society of Captive: A Study of a Maximum Security Prison. Princeton: Princeton University Press, 1958.

von Lampe, Klaus, ed. Organized Crime: Analysing Illegal Activities, Criminal Structures., and Extra-legal Governance. London: Sage, 2016. 